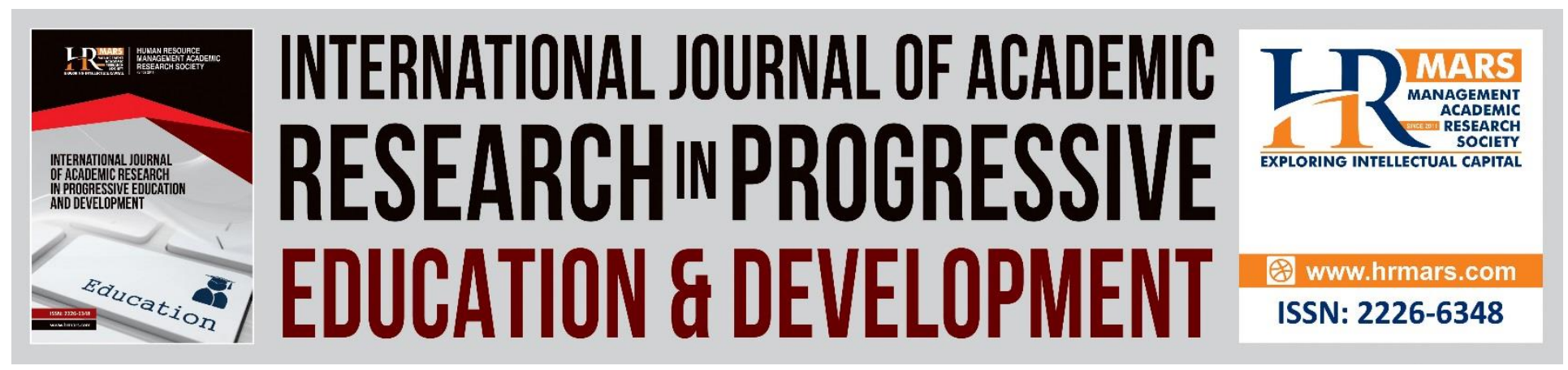

\title{
An Augmented Reality (AR) Approach in Educational Integration of Du'a in Islam
}

Wan Mohd Khairul Firdaus Wan Khairuldin, Abdul Hanis Embong, Wan Nur Izzati Wan Nor Anas, Daud Ismail, Wan Khairul Aiman Wan Mokhtar

To Link this Article: http://dx.doi.org/10.6007/IJARPED/v8-i1/5498 DOI: $10.6007 /$ IJARPED/v8-i1/5498

Received: 18 Dec 2018, Revised: 16 Jan 2019, Accepted: 06 Feb 2019

Published Online: 14 Feb 2019

In-Text Citation: (Khairuldin, Embong, Anas, Ismail, \& Mokhtar, 2019)

To Cite this Article: Khairuldin, W. M. K. F. W., Embong, A. H., Anas, W. N. I. W. N., Ismail, D., \& Mokhtar, W. K. A. W. (2019). An Augmented Reality (AR) Approach in Educational Integration of Du'a in Islam. International Journal of Academic Research in Progressive Education and Development, 8(1), 32-39.

Copyright: (C) 2019 The Author(s)

Published by Human Resource Management Academic Research Society (www.hrmars.com)

This article is published under the Creative Commons Attribution (CC BY 4.0) license. Anyone may reproduce, distribute, translate and create derivative works of this article (for both commercial and non-commercial purposes), subject to full attribution to the original publication and authors. The full terms of this license may be seen at: http://creativecommons.org/licences/by/4.0/legalcode

Vol. 8, No. 1, 2019, Pg. 32 - 39 


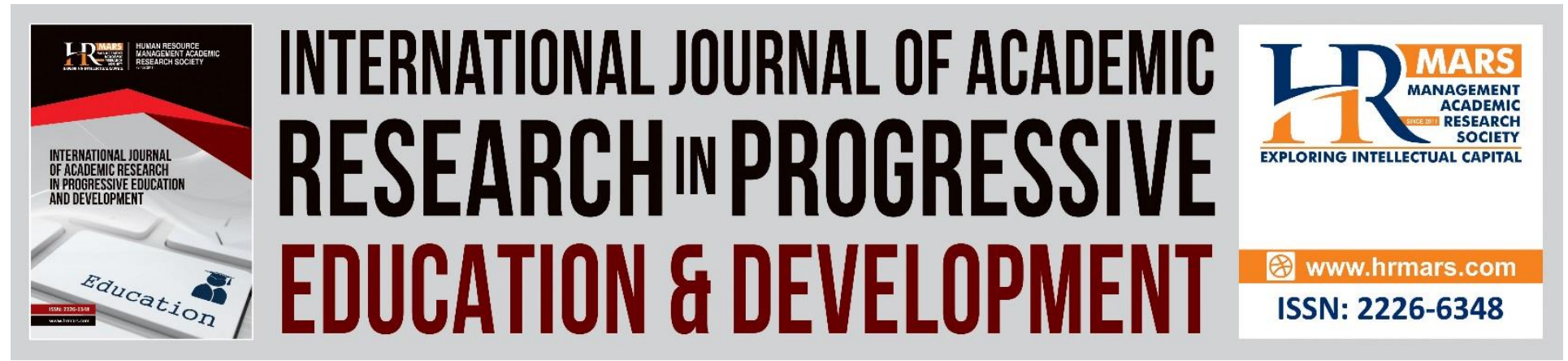

\title{
An Augmented Reality (AR) Approach in Educational Integration of Du'a in Islam
}

\author{
Wan Mohd Khairul Firdaus Wan Khairuldin \\ Research Institute for Islamic Product \& Civilization (INSPIRE), Universiti Sultan Zainal Abidin, \\ MALAYSIA
}

Abdul Hanis Embong

Centre for Fundamental and Liberal Education, Universiti Malaysia Terengganu, MALAYSIA

Wan Nur Izzati Wan Nor Anas

Academy of Islamic Studies, University of Malaya, MALAYSIA

\section{Daud Ismail, Wan Khairul Aiman Wan Mokhtar}

Faculty of Islamic Contemporary Studies, Universiti Sultan Zainal Abidin, MALAYSIA

\begin{abstract}
The formation of a harmonious and prosperous society begins with inculcating noble moral values among society. In Islam, the cultivation of these noble moral values begins with spiritual practices that have been cultivated since childhood such as du'a (praying), meditation and so on. Although such spiritual practices such as du'a practices are seen as trivial, but it has a great impact on the lives of the people. In fact, the large number of prayers and variety has made it difficult for Muslims to practice it in life. With technological development, the role of this du'a is able to be reinforced. Learning through e-learning includes the augmented reality (AR) approach is an effective form of learning and can solve this problem. This article has two main objectives. First, explain the role and importance of praying in the Muslim community. Second, explains the AR approach to learning to help prayer education. To achieve both objectives, library methods and content analysis are carried out. The findings of the study show that du'a can form personal and enhance the spirit of brotherhood in society. In addition, the AR approach is particularly suited to enhancing the understanding and practice of prayer to the Muslim community.
\end{abstract}

Keywords: Augmented Reality, du'a, E-Learning, Muslim, Education 


\section{INTRODUCTION}

A prosperous country starts with a virtuous society and a peaceful environment. In order to archive this matter, Islam encourages its people to focus on religious values by practicing spiritual or spiritual practices (Ghani \& Mansor, 2006). According to Ismail \& Omar (2017), spiritual practices can form a person's personality. There are several spiritual practices organized by Islam and one of them is du'a (prayer).

Du'a is a mediator between humans and their creators. Islam strongly emphasizes the confidence of the slave towards the creator. Du'a or prayer is also a manifestation of humility and the hope of a servant who always hopes for its creator. Du'a or prayer is also a form of spiritual development to every Muslim. This is because every Muslim depends on God in all their lives (Mamat et al., 2016; Khairuldin, 2016).

According to Hamsah and Mahyan (2017), because the reason for not memorizing the text of prayer, Muslims have mostly left prayer. some of them take it easy to perform the du'a (prayer) in their lives.

Therefore, every act done by Muslims has certain prayers. Even when a Muslim has any problem, praying is one of the things organized by Islam. This can be seen in the word of Allah S.W.T alGhaffir verse 60 which means "Pray to Me, and I will accept your prayers" (al-Ghaffir, 40: 60)

Therefore, it is clear that praying is something that Islam claims and is considered as worship (Mamat et al., 2009). Seeing the importance of prayer in Muslim life, prayer-related education needs to be improved. The Augmented Reality (AR), which includes Virtual Reality are promised to be a new technology to develop Virtual Environments where the learner interacts with virtual objects (Carmigniani et al, 2011). Therefore, this AR approach can be used to increase understanding and practice of religion to Muslims.

\section{METHODOLOGY}

Data collection for this study uses document analysis method to get a clear picture of the role of prayer for society. In addition, this method also conducted to obtain clarification on the importance of praying practices in society. Therefore, this study focuses on collecting data from the sources of classical and contemporary books.

The result of this data collection will be analyzed using content analysis method. Content analysis is used to examine and explain the interpretation contained in the document. According to Yusof (2004) and Krippendorff (2004), content analysis is a research technique by making systematic and objective conclusions through documented data. While Marican (2005: 170) and Lebar (2009) define content analysis as an explanation systematically researching textual expressions. It coincides with the data collected from certain documents involving works of writing. In the case of this study, content analysis is to get a clearer picture of the role and importance of praying to the community. 


\section{DISCUSSION}

Discussion of this article has two sections. The first part is to explain the importance of praying practices to the Muslim community. Secondly, discussions on AR approach in learning related to du'a.

\section{The Importance of Praying Practices To The Muslim Community}

Praying is something that is claimed in Islam. Therefore, it is certain that what is claimed in religion like du'a plays an important role in individual life and also affects the society (Khairuldin, 2016). There are several roles of praying practices towards the Muslim community in particular. Among them are:

First: the practice of praying forms a noble personal. Praying is one of the practices of worship that connects the concept of the relationship between the servant and his God or known as devotion. The purpose of this law is to establish a continuous relationship between the servant and his God and not to make the slaves slave of remembrance of Allah S.W.T. According to alQaradawi (1975), the claimed and ordered worship is aimed at forming noble personalities.

Application of prayer practices among children can apply religious values among themselves. By praying, children are taught to depend on God in every way they do. In fact, by praying, they are reserved for remembering what they do. This can certainly shape the children's personality to fear the god. When they fear the God they will not try to do bad things or be threatened by religion when they become adults (Basri et al., 2014).

In some of Islamic country such as Malaysia, the typical Muslim children who attend school at pre-school are taught some prayers before reaching adolescent age. This is a measure of preparation before they face (before puberty) for them to make every act that begins prayer or ending with prayer worth as worship (Sazali, 2010). By familiarizing the children with the practice of praying they will not do anything without praying first. It is clear that noble personal formation begins with a small age through prayer practice.

\section{Second: Praying practice increases motivation}

Generally, prayer practice is one of the religious practices. Those who believe in the existence of God will surely make the prayer as one way to get closer to God. According to Mamat et al. (2009), prayer is one of the contributions to self-motivation. This is possible because the practice of prayer is related to self-devotion to God.

According to al-Ghazali (1972), the increasing of one's devotion to its creator, makes one become increasingly obedient. When one obeys the creator then one has a high understanding of qadha' and qadar concept. And the decree set by God is that someone will get something out of what he's working on. So it is clear that through the practice of praying, the community is applied with high motivation in doing something because of the practice of prayer that teaches the sense of worship and obedience to God S.W.T. 
Third: prayer practice can foster the spirit of brotherhood. Indeed, Islam is a religion that fosters the spirit of brotherhood. Islam is a religion that implements in nature to help others who are in trouble even though themselves cannot afford to help out of material. At least by praying to those in distress can help them in terms of emotion.

Based on the three roles of the mentioned prayer practice, it is clear that the practice of praying plays a major role in the Muslim community in particular. Prayer practices need to be applied since childhood so that the social life of the community is in harmony. Therefore, prayer-related education needs to be streamlined in order to equip every Muslim as individual with prayer recitation. therefore, the use of technology needs to be utilized to get better results.

\section{Augmented Reality (AR) approach in learning related to du'a}

According to Galigo (2006), Islam is always exploiting and accepting the development of this technology in muslim life. The dissemination of information related to Islam is changing clearly using the latest technology. As for result, every Muslim community has the opportunity to obtain information related to Islam. This is also demanded by Islam, which refers to the spread of Islamic teachings as long as it does not contradict Islamic law (Khairuldin et al., 2018).

The use of this new technology affects the Muslim community especially in teaching and learning. Rahman et al. (2015) found that religious-related learning produces a positive impact when using the technology. The finding based on the response by respondents in the study. This shows that the use of technology in the learning process is appropriate, especially in the field of Islamic studies.

In fact, in today's learning system, the majority of teachers and educators have a high level of knowledge and acceptance in relation to the use of e-Learning (Japuni \& Yusof, 2012). This involves muslim communities that evolve as technology progresses. The use of electronic technology is part of the process of teaching and learning. This is supported by Suyanto (2005), which concludes the use of ICT and communication help and solve various problems in learning. In fact, the use of technology can also enhance understanding of a learning topic rather than traditional learning.

On the Reality-Virtuality continuum, the AR is one part of the area of Mixed Reality. The AR system consists of adding virtual objects in a real-world environment (Milgram, 1994). Chang (2010) suggested that virtual and augmented reality can improve learners' knowledge and also enhance their motivation to learn with new things.

Since prayer in Islam has many and different numbers in every act and place, the biggest problem faced by Muslims is usually to memorize every reading of the prayer. Most of the prayer-related learning systems are also more concerned with memorization so that it sometimes makes it difficult for Muslims who do not have the good memory to always read the prayer in every practice. 
Furthermore, various studies have found that AR has a great potential in improving learning especially self-learning, so the AR approach can be used to improve the skills and practice of prayer-related Muslims in everyday life.

\section{Practical Design Module}

As a design module, some form of markers that describe a particular situation will be formed. This situation is based on a prayer that will be read by the app users. Among the proposed are the dining table, in the vehicle, toilet and so on. This is because each place has a different form of prayer. The designer will select a marker form whether a particular logo or script is used to describe what the user will do. The display of prayer and audio reading will work once the user points the phone to the provided markers.

\section{Working environment}

Hardware and software: To do the practical activities the learner needs a latest mobile phone to display the virtual environment. The mobile phone needs to have a camera system to capture the augmented reality's marker that has been provided. "AR Doa" software should be downloaded and run. Each marker has been provided in the application. When added to a relevant place, application usage can be implemented.

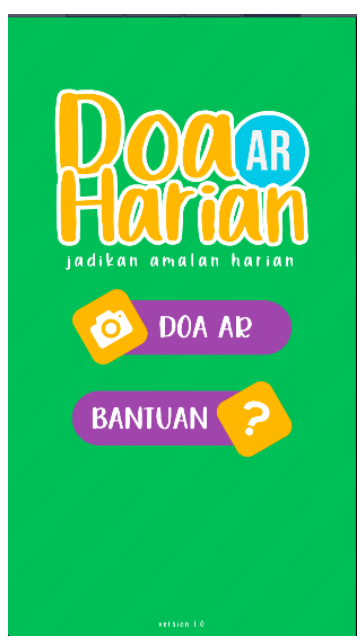

\section{Procedure}

The user or learners starts by downloading the markers that provided from the application. Then, the learners paste the marker in the appropriate place before scan the marker with the application. The app will display the selected prayer together with the audio reading. The app also will provide an explanation of prayer and related matters. At the end, the learner also can take part in the quizzes provided.

\section{CONCLUSION}

In conclusion, du'a or prayer is a form of worship demanded by Islam. Learning for prayer traditionally using the recitation method sometimes makes it difficult for Muslims to practice it consistently in life. Therefore, mobile learning whether e-learning or m-learning needs to be utilized. The AR approach has the advantage of providing the user with the latest learning space 
that can be used as an alternative to existing traditional learning. This approach is still new, but it having a good impact on the social, also can even be improved in the future.

Therefore, AR prayer is a suitable app for solving problems for prayer. Furthermore, this app can be used as one of the forms of mobile learning to the Muslim community regardless of age and background limits.

\section{ACKNOWLEDGEMENT}

Special appreciations to the Research Management, Innovation \& Commercialization (RMIC), University of Sultan Zainal Abidin (UniSZA) for sponsoring the project.

\section{REFERENCES}

al-Ghazali (1972). Al-Munqid min al-Dalal. Cairo: Dar al-Kutub al-Hadithah.

al-Qaradawi, Y. (1975), al-Ibadah fi al-Islam, Beirut: Muassah ar-Risalah.

Basri, T.H., Badaruddin, F. \& Mohamad, A.M. (2014). Konsep Zikir Darajah dalam Disiplin IImu Tarekat, Jurnal Islam dan Masyarakat Kontemporari. 8 (2014). 61-72.

Carmigniani, B., Furht, M., Anisetti, P. Ceravolo, Damiani, \& Ivkovic, (2011). Augmented reality technologies, systems and applications, Multimed. Tools Appl., vol. 51. 341-377.

Ghani, Z.A. \& Mansor, N.S. (2006), Penghayatan Agama Sebagai Asas Pembangunan Pelajar:Analisis Terhadap Beberapa Pandangan al-Imam al-Ghazali, Proceeding in National Student Development Conference (NASDEC) 2006, 8-9 August 2006, Kuala Lumpur, Malaysia.

Ismail, N.N. \& Omar, S.H.S. (2017), Kerohanian Islam:Penghayatan dari Sudut Amalannya, Proceeding of International of Conference of Empowering Islamic Civilization, Universiti Sultan Zainal Abidin.

Khairuldin, W. M. K. F. W. (2018). Fatwa Role in Education and Legal Dispute in Malaysia.

International Journal of Academic Research in Progressive Education and Development, 7(4), 295-302.

Khairuldin, W. M. K. F. W., Anas, W. N. I. W. N., \& Embong, A. H. (2018). The Binding of Laws to Personal Opinion of Muftis in Malaysia. International Journal of Academic Research in Business and Social Sciences, 8(11), 522-529.

Khairuldin, W. M. K. F. W., Anas, W. N. I. W. N., \& Embong, A. H. (2018). Fatwa as a Disseminator of Islamic Laws among Community of Malaysia. International Journal of Academic Research in Business and Social Sciences, 8(11), 516-521.

Khairuldin, W. M. K. F. W., Embong, A. H., Anas, W.N.I.W.N., Mohd, H. \& Ismail, D. (2018). The Application of Technology in the Dissemination of Fatwas: A Study on Religious Institutions in Malaysia, International Journal of Civil Engineering and Technology, 9(7), 2018, pp. 15901596.

Khairuldin, W.M.K.F.W. (2010), Metode Fatwa Sheikh 'Ali Jumaa'ah dalam Kitab al-Kalim alTayyib- Fatawa 'Asriyyah. Unpublished Master Thesis. University of Malaya.

Khairuldin, W.M.K.F.W. (2016), Konsep Fatwa dalam Islam. Kuala Terengganu: Penerbit Universiti Sultan Zainal Abidin. 
Khairuldin, W.M.K.F.W., Ismail, D., Anas, W.N.I.W.N., Ibrahim, I., \& Fauzi, N. (2016). Freedom of Speeches by Mufti According to Islam: Implication to Fatwa in Malaysia. International Journal of Academic Research in Business and Social Sciences. 6 (12). Pp 141-151.

Krippendorff, K. (2004). An introduction to its methodology. Thousand Oaks, CA: Sage.

Mamat, M.S., Hassan, S. N. S. \& Tamuri, A.H. (2009), Amalan Ibadat Harian dan Sumbangannya kepada kecerdasan emosi remaja. JIAE:Journal Islamic and Arabic Education, Jil.1, bil.1.

Mazlan, N. S., \& Khairuldin, W. M. K. F. W. (2018). The Concept of Ta'awun in the Scientific Writing according to Al-Quran. International Journal of Academic Research in Business and Social Sciences, 8(11), 932-940.

Milgram, H. Takemu A., Utsumi, \& Kishino, F. (1994). Mixed Reality (MR) Reality - Virtuality (RV) Continuum, Syst. Res. 2351, pp. $282-292$.

Sazali, H. (2010), Pendidikan Awal-Kanak-Kanak menurut al-Quran:Pelaksanaan di Pusat Pendidikan Pra Sekolah di Bandar Triang Pahang, Master Thesis. Akademi Pengajian Islam Universiti Malaya, Not Published.

Yasin, M.F.M., Embong, A.H., Khairuldin, W.M.K.F.W., Rahim, R.S.A., Abdullah, A., Said, S. \& Mutalib, N.A. (2018). Contributions of Technology Towards Development Of Qur'anic Tajweed Knowledge, International Journal of Civil Engineering and Technology, 9(6), 2018, pp. 1340-1352.

Yusof, R. (2004). Social science research. Bentong, Pahang: PTS Publications \& Distributors. 